\title{
UJI TOKSISITAS EKSTRAK DAUN PLETEKAN (Ruellia tuberosa L ) DENGAN PELARUT ETANOL DAN N- HEKSAN MENGGUNAKAN METODE BRINE SHRIMP LETHALITY TEST (BSLT)
}

\author{
*)Zulfiah \\ *)Akademi Farmasi Sandi Karsa Makassar \\ *)Program Studi D-III Farmasi Sandi Karsa Makassar
}

\begin{abstract}
ABSTRAK
Penelitian ini bertujuan mengetahui uji toksisitas daun pletekan dengan menggunakan pelarut Etanol dan n-heksan. Desain penelitian ini yang digunakan adalah eksperimental laboratorium yang dilaksanakan di Kampus Akademi Farmasi Sandi Karsa Makassar. Pletekan (Reullia tuberose L) dapat mengobati beberapa penyakit antara lain sebagai antidiabetes.antihipertensi dan analgesic.Daun pletekan mengandung sejumlah senyawa bioaktif seperti alkaloid ,flavonoid, steroid dan tannin. Penelitian ini bertujuan untuk mengetahui efek toksik dengan menentukan nilai LC50 dari ekstrak daun pletekan dengan pelarut Etanol dan n-Heksan. Pada penelitian ini daun pletekan diekstrasi menggunakan metode meserasi dengan pelarut Etano dan n-Heksan. Pengujian toksisitas dilakukan menggunakan metode Brine Shrimp Lethality Test (BSLT) untuk membunuh Artemia salina L. Dengan \% konsentrasi yaitu 20ppm, 40ppm, 60ppm, 80ppm dan 100ppm. Berdasarkan hasil didapatkan ekstrak n-Heksan memiliki aktivitas toksisitas yang paling kuat untuk membunuh Artemia salina Leach nilai toksisitas yaitu 123,03 ppm dibandingkan dengan ekstrak Etanol 147,91 ppm.
\end{abstract}

Kata Kunci: Reullia tuberose L, BSLT, LC50

\section{PENDAHULUAN}

\section{A. Latar Belakang}

Keberadaan dan pengembangan obat herbal menjadi kebijakan World Health Organization (WHO) dalam menangani kesehatan dunia. Keberadaan senyawa aktif dalam tumbuhan yang memberikan efek sebagai obat dapat dimengerti mengingat tumbuhan pada tahap awal melakukan proses fotosintesis menghasilkan glukosa, yang selanjutnya melalui proses biokimia tumbuhan menghasilkan metabolit sekunder yang berguna bagi tumbuhan sendiri dan bagi lingkungannya (termasuk khasiat sebagai obat untuk manusia) (Supriyatna, dkk, 2015).

Pengobatan secara tradisional dengan memanfaatkan bahan alami telah diakui masyarakat lebih aman dari pada menggunakan obat sintetik yang memiliki banyak efek samping (Ayu, dkk 2016 ). Tidak semua metabolit sekunder dapat berguna sebagai obat herbal apabila fungsi atau takarannya tidak memadai. Inilah salah satu masalah obat herbal, untuk itu uji toksisitas terhadap bahan herbal perlu dilakukan (Supriyatna, dkk, 2015).

Senyawa toksik merupakan suatu senyawa atau zat yang dapat merusak sel normal dan sel kanker dan juga dapat digunakan untuk menghambat pertumbuhan sel tumor.Untuk mengetahui suatu senyawa memiliki potensi sebagai anti tumor dan anti kanker maka dapat dilakukan penelitian awal, salah satunya melalui uji toksisitas menggunakan metode Brine
Shrimp Lethality Test (BSLT). Metode BSLT ini memiliki banyak keuntungan diantaranya waktu pelaksanaan yang cepat, biaya lebih murah, praktis, tidak memerlukan teknis yang aseptis, sampel yang relative sedikit dan hasil ujinya berkorelasi baik dengan beberapa metode uji toksisitas (Purwanto, 2015).

Tumbuhan pletekan (Ruellia tuberosa Linn), suku Acanthaceae merupakan tanaman hias yang popular di luar negeri (Afzal, dkk 2015).Tumbuhan pletekan memiliki akartuberous yang membantu spesies tersebut mampu bertahan hidup pada musim kemarau, dan memiliki biji yang dapat membantu perkembangbiakannya. Biji pletekan memiliki cangkang yang jika terkena tetesan air akan pecah (terbuka) dan menyebar, perilaku eksplosif yang memiliki suara letupan khas membuat tanaman ini dikenal dengan sebutan "tumbuhan pletekan" (Daya, dkk 2010). Tumbuhan pletekan berkhasiat sebagai antidiabetes, antihipertensi, antipiretik, dan analgesic (Dyah, dkk, 2015).

Studi yang telah dilakukan Vitalia, dkk (2016) tentang analisis fitokimia dan uji toksisitas ekstrak daun pletekan menggunakan tiga pelarut yang berbeda kepolarannya yaitu pelarut non polar (n-heksan), pelarut semipolar (etil asetat), dan pelarut polar (etanol) menunjukkan bahwa ekstrak yang bersifat toksik yaitu ekstrak etil asetat dan ekstrak etanol dengan nilai $\mathrm{LC}_{50}$ sebesar $453,941 \pm 0,76 \mu \mathrm{g} / \mathrm{mL}$ dan $142,160 \pm 1,30$ $\mu \mathrm{g} / \mathrm{mL}$. 
Berdasarkan uraian tersebut di atas maka telah dilakukan uji toksisitas ekstrak daun pletekan dengan variasi pelarut yang berbeda yaitu pelarut non polar (n-Heksan), semi polar (Etanol), Menggunakan Metode Brine Shrimp Lethality Test (BSLT).

\section{B. Rumusan Masalah}

1. Apakah ekstrak Daun Pletekan dengan beberapa pelarut memiliki efek toksik terhadap larva Artemia salina Leach?

2. Berapa nilai $\mathrm{LC}_{50}$ dari ekstrak daun pletekan denganpelarut Etanol dan N-Heksan?

\section{Tujuan Penelitian}

1 Mengetahui efek toksik ekstrak daun pletekan denganpelarut Etanol dan Nheksan.

2 Menentukan kadar konsentrasi toksik dari ekstrak daun pletekan dengan pelarut Etanol dan N-heksan.

\section{Manfaat Penelitian}

1. Manfaat penelitian yaitu dapat memberikan informasi ilmiah

2. Tentang tumbuhan obat yang memberikan efek toksikdan potensipenelitian serta dapat melengkapi dan ilmiah mengenai tumbuhan pletekan.

3. Sebagai bahan tambahan pengetahuan bagi penulis sendiri maupun pembaca

\section{METODE PENELITIAN}

\section{A. Jenis Penelitian}

Jenis penelitian ini yaitu penelitian eksperimen untuk mengetahui Uji Toksisitas Ekstrak Daun Pletekan (Ruellia Tuberosa L ) Dengan Pelarut Etanol Dan N- Heksan Menggunakan Metode Brine Shrimp Lethality Test (BSLT).

\section{B. Lokasi dan Waktu Penelitian}

Penelitian ini dilakukan di Laboratorium Farmasetika dan Laboratorium Farmakognosi \& Fitokimia Jurusan Farmasi Politeknik Sandi Karsa Makassar pada Bulan Maret 2020.

\section{Alat dan bahan}

Alat-alat yang digunakan dalam penelitian ini adalah aerator, akuarium, alat-alat gelas, aluminium foil, batang pengaduk, cawan porselin, kertas saring, lampu pijar 15 watt, mikropipet, neraca analitik, pipet tetes, seperangkat alat maserasi, timbangan kasar, vacum rotary evaporator dan vial.

Bahan yang digunakan adalah aquadest, Aseton, $\mathrm{CH} 3 \mathrm{COOH}, \mathrm{CH} 3 \mathrm{COOHanhidrat,}$ dimetilsulfoksida 2\% (DMSO 2\%), ekstrak daun pletekan, etanol 70\%, $\mathrm{FeCl} 3$, garam tidak beriodium, $\mathrm{H} 2 \mathrm{SO} 4$ pekat, $\mathrm{HCl} 2 \mathrm{~N}, \mathrm{HCl}$ pekat, kloroform, n-Butanol,telur Artemia salina L.(Supreme Plus), pereaksi Dragendroff, pereaksi Mayer,pereaksi Wagner, ragi dan serbuk magnesium.

\section{Pengolahan Sampel}

Tumbuhan pletekan berdaun tunggal diambil didaerah Sengkang, kemudian sampel daun yang diperoleh disortasi basah lalu dicuci. Sampel selanjutnya dirajang dan dikeringkan kemudian dilakukan sortasi kering.

\section{E. Pembuatan Ekstrak}

Ekstraksi komponen aktif dilakukan dengan cara ekstraksi maserasi/perendaman dengan pelarut yang memiliki tingkat kepolaran yang sudah kering yaitu etanol dan n-heksan. Daun pletekan ditimbang sebanyak $200 \mathrm{~g}$ dimasukkan ke dalam maserator ditamabahkan dengan cairan penyari masing- masing sebanyak $2 \mathrm{~L}$ yaitu etanol wadah pertama dan n-heksan pada wadah. Selanjutnya dimaserasi selama 24 jam dengan sesekali diaduk, kemudian disaring.Kemudian hasil sarinya diremaserasi dengan pelarut dan perlakuan yang sama sehingga diperoleh maserat kedua dan ketiga, lalu maserat satu, dua, dan tiga dapat digabung. Maserat yang diperoleh dipekatkan dengan rotary evaporator sampai diperoleh ekstrak pekat Etanol dan N-heksan (Anisetus, 2015).

\section{F. Skrining Fitokimia}

a. Pengujian Alkaloid

Ekstrak dimasukkan dalam tabung reaksi dan diencerkan dengan etanol $70 \%$, kemudian ditambahkan 5 tetes $\mathrm{HCl} 2 \mathrm{~N}$ selanjutnya dipanaskan dan disaring. Dipipet $1 \mathrm{ml}$ dan dimasukkan dalam tabung reaksi, dimana masing-masing tabung reaksi ditambahkan pereaksi dragendorf, perekasi mayer dan pereaksi wagner.

Terbentuknya endapan menunjukkan bahwa sampel tersebut mengandung alkaloid. Reaksi dengan pereaksi mayer akan terbentuk endapan putih, dengan pereaksi dragendorff terbentuk endapan merah jingga dan dengan pereaksi wagner terbentuk endapan coklat (Harborne, 1996).

b. Pengujian Flavonoid

Ekstrak dicampur dengan $3 \mathrm{~mL}$ etanol $70 \%$, lalu dikocok, dipanaskan, dan dikocok lagi kemudian disaring. Filtrat yang diperoleh, kemudian ditambah serbuk $\mathrm{Mg}$ 0,1 g dan 2 tetes $\mathrm{HCl}$ pekat. Terbentuknya warna orange, merah, atau kuning menunjukkan adanya flavonoid (Harborne, 1996). 
c. Pengujian Steroid/Triterpenoid

Ekstrak ditambahkan dengan $1 \mathrm{ml}$ kloroform lalu dikocok.Masing-masing asetat anhidrat dan $\mathrm{H} 2 \mathrm{SO} 4$ sebanyak 2 ditambahkan pada filtrat uji positif steroid jika menghasilkan warna biru atau hijau, sedangkan triterpenoid menghasilkan warna merah atau ungu (Harbone, 1996).

d. Pengujian Saponin

Ekstrak didihkan dengan $10 \mathrm{~mL}$ air dalam penangas air. Filtrat dikocok dan didiamkan. Sampel positif mengandung saponin jika terbentuk buih setinggi $1 \mathrm{~cm}$ selama tidak kurang dari 10 menit dan pada penambahan 1 tetes $\mathrm{HCl} 2 \mathrm{~N}$ buih tidak hilang (Harborne, 1996).

e. Pengujian Tanin

Ekstrak ditambahkan beberapa tetes (23 tetes) $\mathrm{FeCl} 3$, jika berwarna hijau kehitaman berarti sampel mengandung tannin pirogalol, dan bila dihasilkan warna hijau berarti sampel mengandung tannin katekol (Harborne, 1996).

\section{G. Pengujian Brine Shrimp Lethality Test}

1. Penetasan larva Artemia salina Leach

Penetasan larva Artemia salina Leach dilakukan selama 48jam. Penetasan dilakukan dengan cara merendam telur tersebut dalam air laut buatan (50 gram garam tidak beriodium dalam $1,2 \mathrm{~L}$ aquadest) pada akuarium. Sebelumnya akuarium dipasang aerator, aerator ini berguna untuk menjaga kadar oksigen dalam akuarium. Akuarium yang telah terisi telur dan telah dipasangi aerator selanjutnya diletakkan di ruang yang cukup cahaya. Cahaya ini berfungsi untuk pertumbuhan larva Artemia salina L. Dalam waktu 24 jam telur akan berubah menjadi larva Artemia salina L. (Arnanda, 2018).

2. Pembuatan larutan stok

Ekstrak daun pletekan (Etanol dan nHeksan) yang akan diuji, masing-masing ditimbang sebanyak $30 \mathrm{mg}$ kemudian dilarutkan dengan DMSO 2\% 1-3 tetes (50$150 \mu \mathrm{L})$ untuk melarutkan ekstrak lalu ditambahkan $30 \mathrm{~mL}$ air laut sehingga diperoleh konsentrasi 1000 ppm. Masingmasing ekstrak kemudian diencerkan sehingga diperoleh konsentrasi 20,40,60,80, dan $100 \mathrm{ppm}$

3. Pelaksaan pengujian

Sepuluh ekor larva dimasukkan kedalam tiap-tiap vial uji yang telah diberi sedikit air laut dan tambahkan satu tetes larutan ragi sebagai nutrisi larva, kemudian volume air laut dicukupkan sampai $10 \mathrm{~mL}$, sedangkan larutan ragi dan larva udang.
Vial-vial uji kemudian didiamkan pada suhu kamar selama 24 jam .Setiap perlakuan diulang sebanyak tiga kali (triplo). Jumlah larva yang hidup dihitungdan ditentukan presentase kematian larva untuk mengetahui nilai LC50. Exstrak yang mempunyai nilai LC50 < 1000 ppm larva dapat dihitung dengan rumus sebagai. Data yang diperoleh selanjutnya akan dianalisis dengan analisis probit untuk menentukan harga LC50 (Dewanti, 2018).

\section{HASIL DAN PEMBAHASAN}

\section{A. Hasil Penelitian}

Tabel I. Perhitungan Hasil Ekstraksi

\begin{tabular}{cccc}
\hline Sampel & $\begin{array}{c}\text { Bobot } \\
\text { simplisia }(\mathrm{g})\end{array}$ & $\begin{array}{c}\text { Bobot } \\
\text { ekstrak (g) }\end{array}$ & Rendemen \\
\hline $\begin{array}{c}\text { Ekstrak } \\
\text { Etanol }\end{array}$ & 200 & 11.7 & $5.85 \%$ \\
\hline $\begin{array}{c}\text { Ekstrak } \\
\text { n-Heksan }\end{array}$ & 200 & 2.9 & $1.45 \%$ \\
\hline
\end{tabular}

Tabel II. Identifikasi Kualitatif

\begin{tabular}{|c|c|c|c|c|c|}
\hline Ekstrak & $\begin{array}{l}\text { Pereaksi } \\
\text { spesifik }\end{array}$ & $\begin{array}{c}\text { Warna } \\
\text { yang } \\
\text { dihasil } \\
\text { kan }\end{array}$ & $\begin{array}{c}\text { Litera } \\
\text { tur }\end{array}$ & Pustaka & Ket \\
\hline \multirow{10}{*}{$\begin{array}{c}\text { Ekstrak } \\
\text { Etanol }\end{array}$} & & Alkaloid & & \multirow{10}{*}{$\begin{array}{c}\text { Harborne, } \\
1996\end{array}$} & \multirow[t]{2}{*}{-} \\
\hline & $\begin{array}{c}\text { Dragen } \\
\text { dorf }\end{array}$ & $\begin{array}{c}\text { Tidak } \\
\text { terbentuk } \\
\text { endapan, } \\
\text { warna } \\
\text { hijau }\end{array}$ & $\begin{array}{c}\text { Endapan } \\
\text { merah/ } \\
\text { jingga }\end{array}$ & & \\
\hline & Mayer & $\begin{array}{c}\text { Tidak } \\
\text { terbentuk } \\
\text { endapan, } \\
\text { warna } \\
\text { coklat }\end{array}$ & $\begin{array}{l}\text { Endapan } \\
\text { putih }\end{array}$ & & - \\
\hline & Wagner & $\begin{array}{c}\text { Tidak } \\
\text { terbentuk } \\
\text { endapan, } \\
\text { warna } \\
\text { hijau }\end{array}$ & $\begin{array}{c}\text { Endapan } \\
\text { coklat }\end{array}$ & & - \\
\hline & \multicolumn{3}{|c|}{ Flavonoid } & & \multirow[t]{2}{*}{+} \\
\hline & $\begin{array}{c}\text { Serbuk } \\
\mathrm{Mg}+ \\
\mathrm{HCl} \\
\text { pekat } 2 \\
\text { tetes }\end{array}$ & Kuning & $\begin{array}{c}\text { Merah, } \\
\text { kuning } \\
\text { atau } \\
\text { orange }\end{array}$ & & \\
\hline & \multicolumn{3}{|c|}{ Steroid/Triterpenoid } & & \multirow[t]{2}{*}{+} \\
\hline & $\begin{array}{c}\text { Klorofor } \\
\text { m } 1 \mathrm{ml}+ \\
\text { asetat } \\
\text { anhidrat } \\
+\mathrm{H}_{2} \mathrm{SO}_{4}\end{array}$ & $\begin{array}{c}\text { Hijau } \\
\text { kehitaman }\end{array}$ & $\begin{array}{c}\text { Biru/ hijau } \\
\text { (Steroid) } \\
\text { Merah/ } \\
\text { ungu } \\
\text { (Triter } \\
\text { penoid) }\end{array}$ & & \\
\hline & \multicolumn{3}{|c|}{ Saponin } & & - \\
\hline & $\begin{array}{c}\text { Air } \\
\text { panas }+ \\
\mathrm{HCl} 2 \mathrm{~N}\end{array}$ & $\begin{array}{c}\text { Tidak } \\
\text { terbentuk } \\
\text { busa }\end{array}$ & $\begin{array}{l}\text { Terbentuk } \\
\text { busa }\end{array}$ & & \\
\hline
\end{tabular}




\begin{tabular}{|c|c|c|}
\hline \multicolumn{2}{|l|}{ Tanin } & \multirow[t]{3}{*}{+} \\
\hline $\begin{array}{c}\text { Hijau } \\
\text { kehitaman }\end{array}$ & $\begin{array}{c}\text { Hijau } \\
\text { kehita } \\
\text { man } \\
\text { (Tanin } \\
\text { pirogalo) }\end{array}$ & \\
\hline & $\begin{array}{c}\text { Hijau } \\
\text { (Tanin } \\
\text { Katekol) }\end{array}$ & \\
\hline Lite ratur & Pustaka & Ket \\
\hline & \multirow{12}{*}{$\begin{array}{c}\text { Harborne, } \\
1996\end{array}$} & \multirow[t]{2}{*}{-} \\
\hline $\begin{array}{c}\text { Endapan } \\
\text { merah/ } \\
\text { jingga }\end{array}$ & & \\
\hline $\begin{array}{l}\text { Endapan } \\
\text { putih }\end{array}$ & & - \\
\hline $\begin{array}{c}\text { Endapan } \\
\text { coklat }\end{array}$ & & - \\
\hline Flavonoid & & \multirow[t]{2}{*}{+} \\
\hline $\begin{array}{c}\text { Merah, } \\
\text { kuning } \\
\text { atau } \\
\text { orange }\end{array}$ & & \\
\hline Steroid/Triterpenoid & & \multirow[t]{2}{*}{+} \\
\hline $\begin{array}{c}\text { Biru/hijau } \\
\text { (Steroid) } \\
\text { Merah/ } \\
\text { ungu } \\
\text { (Triter } \\
\text { penoid) }\end{array}$ & & \\
\hline Saponin & & \multirow[t]{2}{*}{-} \\
\hline $\begin{array}{l}\text { Terbentuk } \\
\text { busa }\end{array}$ & & \\
\hline Tanin & & \multirow[t]{2}{*}{-} \\
\hline $\begin{array}{c}\text { Hijau } \\
\text { kehitaman } \\
\text { (Tanin } \\
\text { (pirogalo) } \\
\text { Hijau } \\
\text { (Tanin } \\
\text { Katekol) }\end{array}$ & & \\
\hline
\end{tabular}

Tabel III. Data Hasil Kematian Larva Artemia salina L. Ekstrak

\begin{tabular}{|c|c|c|c|c|c|c|c|}
\hline \multirow{2}{*}{$\begin{array}{l}\text { Penga } \\
\text { matan }\end{array}$} & \multirow{2}{*}{$\begin{array}{l}\text { Repli } \\
\text { kasi }\end{array}$} & \multirow{2}{*}{$\begin{array}{l}\text { Kontrol } \\
\text { air laut }\end{array}$} & \multicolumn{5}{|c|}{ Ekstrak Etanol daun pletekan } \\
\hline & & & $\begin{array}{c}20 \\
\text { ppm }\end{array}$ & $\begin{array}{c}40 \\
\text { ppm }\end{array}$ & $\begin{array}{c}60 \\
\text { ppm }\end{array}$ & 80 ppm & $\begin{array}{r}100 \\
\text { ppm }\end{array}$ \\
\hline \multirow{4}{*}{$\begin{array}{c}\text { Jumlah } \\
\text { larva awal }\end{array}$} & I & 10 & 10 & 10 & 10 & 10 & 10 \\
\hline & II & 10 & 10 & 10 & 10 & 10 & 10 \\
\hline & III & 10 & 10 & 10 & 10 & 10 & 10 \\
\hline & Total & 30 & 30 & 30 & 30 & 30 & 30 \\
\hline \multirow{4}{*}{$\begin{array}{c}\text { Jumlah } \\
\text { mortalitas }\end{array}$} & I & 0 & 1 & 1 & 2 & 3 & 4 \\
\hline & II & 0 & 0 & 1 & 2 & 2 & 3 \\
\hline & III & 0 & 0 & 0 & 2 & 3 & 4 \\
\hline & Total & $\mathbf{0}$ & 1 & 2 & 6 & 8 & 11 \\
\hline $\begin{array}{c}\% \\
\text { Mortalitas }\end{array}$ & & $\mathbf{0}$ & 3,33 & 6,67 & 20 & 26,6 & 36,6 \\
\hline
\end{tabular}

Tabel IV. Data Hasil Kematian Larva Artemia salina L. Ekstrak n-Heksan Setelah 24 jam.

\begin{tabular}{cccccccc}
\hline Pengamatan & Replikasi & $\begin{array}{c}\text { Kontrol } \\
\text { air laut }\end{array}$ & \multicolumn{3}{c}{ Ekstrak n-Heksan daun pletekan } \\
\cline { 3 - 8 } & & $\mathbf{2 0}$ & $\mathbf{4 0}$ & $\mathbf{6 0}$ & $\mathbf{8 0}$ & $\mathbf{1 0 0}$ \\
Jumlah larva & & & $\mathbf{p p m}$ & $\mathbf{p p m}$ & $\mathbf{p p m}$ & $\mathbf{p p m}$ & $\mathbf{p p m}$ \\
awal & I & 10 & 10 & 10 & 10 & 10 & 10 \\
\cline { 2 - 8 } & II & 10 & 10 & 10 & 10 & 10 & 10 \\
\cline { 2 - 8 } & III & 10 & 10 & 10 & 10 & 10 & 10 \\
\cline { 2 - 8 } & Total & $\mathbf{3 0}$ & $\mathbf{3 0}$ & $\mathbf{3 0}$ & $\mathbf{3 0}$ & $\mathbf{3 0}$ & $\mathbf{3 0}$ \\
\hline Jumlah & I & 0 & 0 & 1 & 2 & 3 & 4 \\
\cline { 2 - 8 } & II & 0 & 1 & 2 & 2 & 3 & 5 \\
\cline { 2 - 8 } & III & 0 & 0 & 2 & 2 & 4 & 4 \\
\hline \%ortalitas & Total & $\mathbf{0}$ & $\mathbf{1}$ & $\mathbf{5}$ & $\mathbf{6}$ & $\mathbf{1 0}$ & $\mathbf{1 3}$ \\
\hline & & $\mathbf{0}$ & $\mathbf{3 , 3 3}$ & $\mathbf{6 , 6}$ & $\mathbf{2 0}$ & $\mathbf{3 3 , 3}$ & $\mathbf{4 2}$ \\
\hline
\end{tabular}

\section{B. Pembahasan}

Penelitian ini menggunakan daun dari tumbuhan pletekan (Ruellia tuberosa L.). Bagian tumbuhan yang digunakan pada pengujian ini yaitu daun pletekan dalam bentuk simplisia kering karena kadar air yang terdapat dalam simplisia pada umumnya lebih sedikit sehingga memudahkan cairan penyari masuk ke dalam sel tumbuhan dan menarik zat aktif yang terkandung secara sempurna.

Proses penyarian (ekstraksi) dilakukan menggunakan metode ekstraksi yang digunakan adalah metode maserasi yang merupakan salah satu metode ekstraksi dingin. Metode ini tidak merusak komponen kimia dari sampel daun Pletekan (Ruellia tuberosa L.) karena tidak adanya pemanasan dalam proses ekstraksi (Dirjen POM, 1986).Daun pletekan yang sudah menjadi serbuk direndam dengan tiga jenis pelarut yang memiliki tingkat kepolaran yang berbeda yaitu etanol, dan n-heksan. Hal ini bertujuan untuk dapat menarik komponen aktif dengan tingkat kepolaran yang berbeda dari setiap pelarut.Maserasi pada serbuk daun pletekan dilakukan 3 x 24 jam, agar pelarut mempunyai waktu interaksi dengan sampel lebih lama. Menurut Silva et al., (1998), selama proses maserasi akan terjadi perbedaan tekanan antara di dalam sel dan di luar sehingga senyawa metabolit sekunder yang ada di dalam sitoplasma akan keluar dan terlarut dalam pelarut yang digunakan. Dari hasil ekstraksi diperoleh rendemen pada kedus jenis pelarut yang berbeda.Banyaknya rendemen bergantung pada sifat kelarutan pada komponen bioaktifnya.Rendemen paling tinggi diperoleh dengan menggunakan pelarut etanol, sehingga kemungkinan besar senyawa bioaktif yang terdapat pada tumbuhan pletekan lebih bersifat polar, hal ini karena pelarut etanol bersifat polar. Rendemen dengan pelarut etanol sebesar $5.85 \%$ kemudian diikuti dengan hasil rendemen pelarut n-heksan sebesar $1,45 \%$. Setelah diperoleh bobot ekstrak kental, selanjutnya dilakukan uji 
skrining fitokimia. Hal ini dilakukan untuk mengetahui keberadaan suatu komponen fitokimia dalam ekstrak yang akan diujikan. Penentuan secara kualitatif dapat dilihat dari perubahan warna atau terbentuknya buih atau endapan jika sampel direaksikan dengan bahan kimia tertentu.Hasil identifikasi kandungan senyawa aktif berdasarkan uji skrining fitokimia dengan reagen pada kedua ekstrak daun pletekan, menunjukkan adanya senyawa alkaloid, flavonoid, steroid, dan tannin, tetapi menunjukkan hasil negatif pada senyawa saponin.

Pengujian efek toksisitas ekstrak daun pletekan dengan pelarut etanol dan n-heksan dilakukan dengan menggunakan metode Brine Shrimp Lethality Test (BSLT). Metode ini merupakan salah satu cara yang banyak digunakan untuk mengetahui potensi batas keamanan dari sampel. Uji toksisitas ini dapat dilakukan dengan mengamati kematian hewan dan respon kematian ini dianggap sebagai pengaruh senyawa yang diuji.Pengujian toksisitas dimaksudkan untuk mengetahui potensi tingkat keamanan pada ekstrak daun pletekan dengan melihat jumlah kematian Artemia salina dan menentukan nilai LC50 (Lethal Concentration 50).

Pengujian efek toksik dari ekstrak daun pletekan dibuat dengan 5konsentrasi yaitu 20 ppm, 40 ppm, 60 ppm, 80 ppm, dan 100 ppm. Hal ini dimaksudkan untuk melihat variasi respon yang diberikan.Penggunaan air laut disini dimaksudkan untuk melihat apakah respon kematian hewan uji benar-benar berasal dari sampel dan bukan disebabkan faktor lain misalnya lingkungan. Larutan ragi digunakan sebagai sumber makanan bagi Artemia salina(Mudjiman, 1989). Pemberian makanan dilakukan pada saat pengujian (larva usia 48 jam). Masing-masing perlakuan diulang sebanyak 3 kali (triplo) dengan maksud untuk mendapatkan data yang akurat atau tepat.

Data perhitungan harga LC50 dengan analisa probit dapat dilihat pada lampiran 6,7 dan 8.Berdasarkan hasil analisa probit diperoleh harga LC50 untuk ekstrak etanol dan n-heksan berturut-turut yaitu $147.91 \mathrm{ppm}, 123.03 \mathrm{ppm}$. Ekstrak etanoldan n-heksan termasuk dalam kategori toksisitas sedang karena berada pada rentang 100-500 $\mu \mathrm{g} / \mathrm{mL}$. (Nguta et al., 2012).

Beberapa kandungan kimia dalam ekstrak daun pletekan yang kemungkinan bersifat toksik yaitu alkaloid, flavonoid, dan steroid karena dapat menghambat daya makan larva (antifedant). Cara kerja senyawa-senyawa tersebut adalah dengan bertindak sebagai stomach poisoning atau racun perut, oleh karena itu, bila senyawa ini masuk ke dalam tubuh larva, alat pencernaannya akan terganggu. Senyawa ini menghambat reseptor perasa pada daerah mulut larva.Hal ini mengakibatkan larva gagal mendapatkan stimulus rasa sehingga tidak mampu mengenali makanannya, dan akibatnya larva mati kelaparan (Rita, dkk.2008).

Berdasarkan data tersebut, memperlihatkan bahwa kedua ekstrak daun pletekan dapat dikategorikan toksik karena memiliki nilai LC50 < 1000 ppm.Hasil analisa probit menunjukkan bahwa ekstrak daun pletekan (Ruellia tuberosa L.) berpotensi sebagai senyawa antitumor atau anti kanker.

\section{PENUTUP}

\section{A. Kesimpulan}

Berdasarkan hasil pengamatan dan analisis data maka, dapat ditarik kesimpulan yaitu:

1. Senyawa metabolit sekunder yang terkandung pada ekstrak daun pletekan adalah alkaloid, flavonoid dan steroid

2. Kedua ekstrak (Etanol dan n-Heksan) mempunyai efek toksik terhadap larva Artemia salina Leach.

3. Ekstrak n-heksan merupakan ekstrak dengan nilai LC50 yang tertinggi dengan nilai LC 750 sebesar 123,03yang termasuk ketegori ketoksikan kuat dengan range 0-100 $\mu \mathrm{g} / \mathrm{mL}$, sedangkan ekstrak etanol dengan nilai LC50 sebesar $147,91 \mu \mathrm{g} / \mathrm{mL}$.

B. Saran

Diharapkan dilakukan penelitian selanjutnya tentang uji toksisitas terhadap sel kanker dari ekstrak Etanol n-heksan daun pletekan (Ruellia tuberosa L.)

\section{DAFTAR PUSTAKA}

Afzal. K, Uzair. M, Bashir.A.C, Ashfaq.A, Samina.A, dan Malik.S. 2015. Genus Ruellia: Pharmacological and Phytochemical Importance in Ethnopharmacology. Polish Pharmaceutical Society. Malaysia

Ahmad A, 2012. Isolasi dan Elusidasi Struktur Antioksidan dan Penghambat Enzim Xantin Oksidase Ekstrak Daun Pletekan (Ruellia tuberosa L). Depok.Universitas Indonesia; Fakultas Matematika dan Ilmu Pengetahuan Alam.

Ayu I.N, Ni Putu A, dan Ngurah I.W. 2016. Identifikasi Senyawa Aktif Daun Pletekan (Ruellia tuberosa $\mathrm{L}$ ) dengan Menggunakan GC-MS. Universitas Udayana. Bali 
Baraja, muna. 2008. Uji Toksisitas Ekstrak Daun Ficus elastic Nois ex Blume Terhadap Artemia Salina Leach dan Profil Kromatografi Lapis Tipis. Universitas Muhammadiyah Surakarta, Surakarta

Carballo, J.L. et al, 2002, A Comparison Between Two Brine Shrimp Assay to Detect in Vitro Cytotoxicity in Marine Natural Products. BMC Biotechnology

Chen, FA, et al. 2006. Evaluation of the Antioxidant Activity of Ruellia tuberosa. Food Chem

Chwan-Fwu Lin et. al. Bioactive flavonoid from Ruellia tuberosa. J Chin Med. 2006; 17(3): 103-109.

Daya.L.C, Patel MB, Mishra SH, Vaghasiya HU. 2010. Review Ruellia Tuberosa (Cracker Plant). PHCOGJ. India

Ditjen POM.1986. Sediaan Galenik. Departemen Kesehatan Republik Indonesia, Jakarta.

Ditjen POM. 1989. Materia Medika Indonesia Jilid 5. Departemen Kesehatan Republik Indonesia, Jakarta.

Ditjen POM. 2000. Parameter Standar Umum Ekstrak Tumbuhan Obat. Departemen Kesehatan Republik Indonesia, Jakarta

Dyah, R.W, Edi, P.U dan Chanif. M. 2015. Antidiabetic Activity of Ruellia tuberosa L, Role of $\alpha$-Amylase Inhibitor : In Silico, In Vitro, and In Vitro Approaches. Hindawi Publishing Corporation. Mesir

Fathiyawat. 2008. Uji Toksisitas Ekstrak Daun (Ficus racemosa L.) Terhadap Artemia salina dan Profil Kromatografi Lapis Tipis. Universitas Muhammadiyah Surakarta. Surakarta.

Harborne, J. B. 1996. Metode Fitokimia. edisi kedua. ITB. Bandung.

Hodgson, E., \& Levy, P.E. 2000.A Textbook of Modern Toxicology, 2nd Ed. McGraw-Hill co, Singapura.

Irma, 2017, Uji Toksisitas Fraksi Daun Majapahit (Crescentia cujete L.) dengan Menggunakan Metode Brine Shrimp Lethality Test (BSLT), Universitas Islam Negeri Alauddin Makassar, Makassar.
Kanwar, A.S,2007, Brine Shrimp (Artemia salina) a Marine Animal for Simple and Rapid Biological Assay. Chinese Clinical Medicine 2 (4): 35-42

Lemmens dan Bunyapraphatsara N. 2003. Plant Resources of South-East Asia No. 12 (3) Medicinal and Poisonous Plants 3 Backhuys Publishers, Leiden.

Mahyuddin, kholish, 2010, Panduan Lengkap Agnibisnis Patin. Swadaya, Jakarta.

Maria AU. 2017. Ekstraksi dan Real Kromatografi. Yogyakarta; Deepublish

McLaughlin, J.L., Rogers,L.L. 1998. The Use of Biological Assays to Evaluate Botanicals. Drug Information Journal.

Meyer, B.N., Ferrigni, N.R., Putnam, J.E., Jacobsen, LB., Nicjols, D.E., dan McLaughin, J.L. 1982. Brine Shrimp: A Convenient General Bioassay for Active Plant Constituent. Planta Medica

Mioara, D. 2001. Artemia salina.Balneo-Reseach Journal Vol 2

Mudjiman, A. 1998. Udang Renik Air Asin Bhrata Karya Aksara, Jakarta.

Musyidi, A. 1984. Statistik Farmasi dan Biologi. Ghalia Indonesia Cetakan 1, Jakarta.

Nguta, J.M., Mbaria J.M., Gakayu D.W.P., Gathumbi K., Kabasa J.D., and Kiama S.G. 2012. Evaluation of Acute Toxicity of Crute Plant Extracts from Kenyan Biodi-versity using Brine Schrimp, Artemia salina $L$. (Artemidae).

Nurhayati, A.P.D. 2006. Uji Toksisitas Ekstrak (Eucheuma alvarezii) Terhadap Artemia salina Sebagai Antikanker. FMIPA, Institut Teknologi Sepuluh November. Surabaya. Akta Kimindo.

Nur J, Ghanaim F, Rachmawati N, dan Ahmad A. 2014. Uji Toksisitas Ekstrak Daun Binahong (Anredera cordifilia (Ten.) Steenis) Terhadap Larva Udang Artemia Salina Leach Dengan Metode Brine Shrimp Lethality Test (BSLT)

Purwanto N. Uji Sitotoksik Ekstrak Biji Salak (Salacca zalacca (Gaert)) dengan Menggunakan Metode Brine Shrimp 
Lethality Test (BSLT). Bandung;

Universitas Islam

Rita, W.S., I.W. Suirta., \& A. Sabikin. 2008. Isolasi dan Identifikasi Senyawa yang Berpotensi sebagai Antitumor pada Daging Buah Pare (Momordica charantia L.). Jurusan Kimia FMIPA Universitas Udayana, Bukit Jimbaran.

Saifudin, Azis. 2014. Senyawa Alam Metabolit Sekunder Teori, Konsep, dan Teknik Pemurnian.Ed.1. Yogyakarta. Deepublish

Silva, G.L., I.S. Momuat \& M. Kumaunang, 2012, Uji Toksisitas dan Skrinning Fitokimia Tepung Gabah Pelepah Aren (Arenga piñata). J. Ilmiah S

Sinaga, Indah, 2014, Uji Toksisitas (LC50-24 Jam) Ekstrak Kulit Jengkol (Pithecellobium jiringa) Terhadap Larva Udang (Artemia salina Leach). Universitas Medan Area, Medan.

Singgih, dkk, Artemia untuk Pakan Ikan dan Udang. Press PS

Sukandarrumidi, dkk. 2018. Geotoksikologi. UGM Press

Supriyatna, R. Maya, Dewanto, Indra.W, DAN Ferry.F. 2015. Fitoterapi Sistem Organ: Pandangan Dunia Barat Terhadap Obat Herbal. Deepublish. Yogyakarta

Tawaha, K.A. 2006. Cytotoxicity Evalution of Jordanian Wild Plants using Brine Shrimp Lethality Test, Journal of Applied, Sciences, $8(1), 12-17$.

Van Steeins, C.G.G.J. 1975. Flora. PT. Pradnya Paramita

Vitalia.N, Ahmad. N, Aktsar. R.A. 2016. Uji Toksisitas Ekstrak Daun Pletekan (Ruellia tuberosa L) dengan Menggunakan Metode BSLT. Universitas Muslim Indonesia. Makassar

Yusuf, dahlan, 2018, Uji Toksisitas Fraksi Methanol Hybroid Aglaophenia cupressina Lamoreoux terhadap Artemia Salina Leach. Universitas Hasanuddin. Makassar. 